\title{
COMPARING LONG-TERM ATMOSPHERIC ${ }^{14} \mathrm{C}$ AND ${ }^{3} \mathrm{H}$ RECORDS NEAR GRONINGEN, THE NETHERLANDS WITH FRUHOLMEN, NORWAY AND IZAN̄A, CANARY ISLANDS ${ }^{14}$ C STATIONS ${ }^{1}$
}

\section{HARRO A. J. MEIJER, JOHANNES VAN DER PLICHT}

\author{
Centrum voor Isotopen Onderzoek, University of Groningen, NL-9747 AG Groningen
}

The Netherlands

\section{JORUNN S. GISLEFOSS and REIDAR NYDAL}

\author{
Radiological Dating Laboratory, NTH, N-7034 Trondheim, Norway
}

\begin{abstract}
We present the results of the ${ }^{14} \mathrm{CO}_{2}$ atmospheric monitoring station at the Smilde observation station, near Groningen, the Netherlands, a typical continental station. We compared these data, for absolute values and annual variation, with data from Fruholmen, Nordkapp, Norway and Izaña, Tenerife, Canary Islands, which are situated in areas less influenced by fossil-fuel $\mathrm{CO}_{2}$. The 20 -yr Smilde record shows much seasonal variation (peak-to-trough variation is $\sim 30 \%$ in contrast to $\sim 12 \%$ for Fruholmen, and $\sim 5 \%$ for Izaña) and a lower overall value due to fossil-fuel consumption, in accordance with findings from similar stations in continental Western Europe. The Fruholmen and Izaña data show fairly equal mean $\Delta^{14} \mathrm{C}$ levels, but differ in seasonal amplitude. This difference could be due partly to the elevation difference between the stations. The Izaña station also has a slow exchange with the ground-level air because of an inversion layer. It is speculative whether annual injection of ${ }^{14} \mathrm{C}$ from the stratosphere also plays a role. We give the Groningen long record of tritium in precipitation, showing profound seasonality.
\end{abstract}

\section{INTRODUCTION}

The ${ }^{14} \mathrm{C}$ content of atmospheric $\mathrm{CO}_{2}$ has been monitored in several places around the world for many years, in some cases dating back to the beginning of nuclear bomb testing (Münnich and Vogel 1958; Nydal and Lövseth 1983; Levin, Münnich and Weiss 1980; Vogel 1970; Manning et al. 1990). Most of these monitoring sites have been chosen for minimal direct continental biospheric and anthropogenic influences. These measurement series have shown their usefulness in supporting modeling of northern-southern hemisphere mixing in the atmosphere, as well as atmosphere-ocean $\mathrm{CO}_{2}$ exchange rates (Nydal 1968; Broecker et al. 1985).

True continental stations, on the other hand, might shed more light on the (spatial and temporal) distribution of fossil-fuel emissions, mainly by providing information about summer $v s$. winter ${ }^{14} \mathrm{Clev}$ els in comparison with "nearby" background sampling stations (Levin et al. 1989). Surprisingly little is known about the summer/winter difference in fossil-fuel consumption on the different continents. Here, we compare the continental Smilde observation station, Netherlands, to background stations: Fruholmen/Nordkapp, Norway, and Izaña/Tenerife, Canary Islands, in absolute value, long-term trends and in annual variation. Data from another station, Schauinsland, in the Black Forest region of Germany, which could be characterized as "continental background" (Levin, Graul and Trivett 1994), are also given for comparison.

\section{METHOD}

The Smilde station is a television broadcasting tower, ca. $40 \mathrm{~km}$ south of Groningen $\left(52^{\circ} 54^{\prime} \mathrm{N}\right.$, $6^{\circ} 24^{\prime} \mathrm{E}$ ). Sample collection methods are similar to those described by Vogel (1970). All samples are collected from a height of $\sim 80 \mathrm{~m}$ above the ground ( $\sim 80 \mathrm{~m}$ above sea level), by gently bubbling air

${ }^{1}$ This paper was presented as a poster at the 15 th International ${ }^{14} \mathrm{C}$ Conference, Glasgow, Scotland, 15-19 August 1994. 
through an $\mathrm{NaOH}$ absorption system. Direct contamination of the surroundings is considered to be small. The $\mathrm{NaOH}$ solution is (nearly always) replaced once a month, so that each measuring point is a true average of a 1-month period. The system is designed to absorb all $\mathrm{CO}_{2}$ that passes through it.

In the laboratory, the $\mathrm{CO}_{2}$ is liberated from the solution again by acidification and stripping, and the collected $\mathrm{CO}_{2}$ is inserted into a proportional gas counter. Typical counting statistics allow for a precision of $\sim 5 \%$. The $\delta^{13} \mathrm{C}$ values obtained for the $\mathrm{CO}_{2}$ resemble the true isotope ratio in the atmospheric $\mathrm{CO}_{2}$, although with considerable scatter for the period between 1974-1985. After 1985, no $100 \%$ stripping yield was reached. This effect gradually became worse until we discovered it to be the cause of the decreasing $\delta^{13} \mathrm{C}$ values. Since January 1993, recollection has occurred with $100 \%$ efficiency, and reliable $\delta^{13} \mathrm{C}$ values are being produced. Of course, this effect has no influence on the normalized ${ }^{14} \mathrm{C}$ values.

Nydal (1966) previously described the Fruholmen and Izaña stations and the preparation technique. The main differences from the Smilde station are that the points are averages over a few days ( 7 days from 1962-1981, and 3-4 days later), and that considerable isotope fractionation occurs (leading to values of $\sim-25 \%$ for $\delta^{13} \mathrm{C}$ ) due to using $\mathrm{NaOH}$ solution exposed to open air. The counting statistics for each $\Delta^{14} \mathrm{C}$ are $c a .10 \%$ from $1962-1981$, and 5\%o thereafter. Of course, the shorter collection time span yields a greater number of points per year than the Smilde series.

\section{RESULTS}

\section{Trends}

Figure 1 is an overview of the data discussed in this paper. The ${ }^{14} \mathrm{C}$ results are given in excess per mil relative to 1950 standard air, corrected for isotopic fractionation and radioactive decay, where

$$
{ }^{14} \Delta=\mathrm{e}^{-\left(\mathrm{F}_{\text {moderm }} / 8033\right)} \mathrm{e}^{((1950-\text { date }) / 8267)}-1(\times 1000 \% 0)
$$

(Stuiver and Polach 1977). ${ }^{2}$

The Smilde station began operation in the early 1960s, stopped in 1964, and resumed in 1974. Vogel (1970) published the early Smilde series. Nydal and Lövseth (1983) published the Izaña and Fruholmen series in both tables and graphs until 1980. Only graphs were published later on (e.g., Nydal 1991; Gislefoss 1994). We give the Smilde series in Appendix 1. Tables of all data from the Trondheim laboratory will be available online in a Carbon Dioxide Information Analysis Center (CDIAC) database.

The curves plotted in Figure 1 are "weighted smooth fits", also called "Loess fits" (Cleveland and McRae 1989). The smoothing factor of this fit procedure can be set so that the time response of the fit procedure is shorter than a year, thereby allowing the curve to follow slow, trend-like changes, but preventing it from following the intra-annual variations. The Fruholmen trend fit has been performed since July 1963. Because of its long duration, the trend yields important information about the troposphere-ocean exchange process. The main feature of the curve is the exponential decay of the atmospheric value caused primarily by uptake of ${ }^{14} \mathrm{C}$ into the oceanic mixed layer (Nydal et al. 1984). Several other effects contribute to the shape of this exponential decay curve, however. At first, the disequilibrium between the northern and southern hemisphere during the 1960s (Nydal

\footnotetext{
2 As it is given here, the Fruholmen signal has been corrected for radioactive decay. This is in contrast to other publications of these data. The differences, however, are small (6\%o in absolute value in 1992), and are most likely negligible.
} 


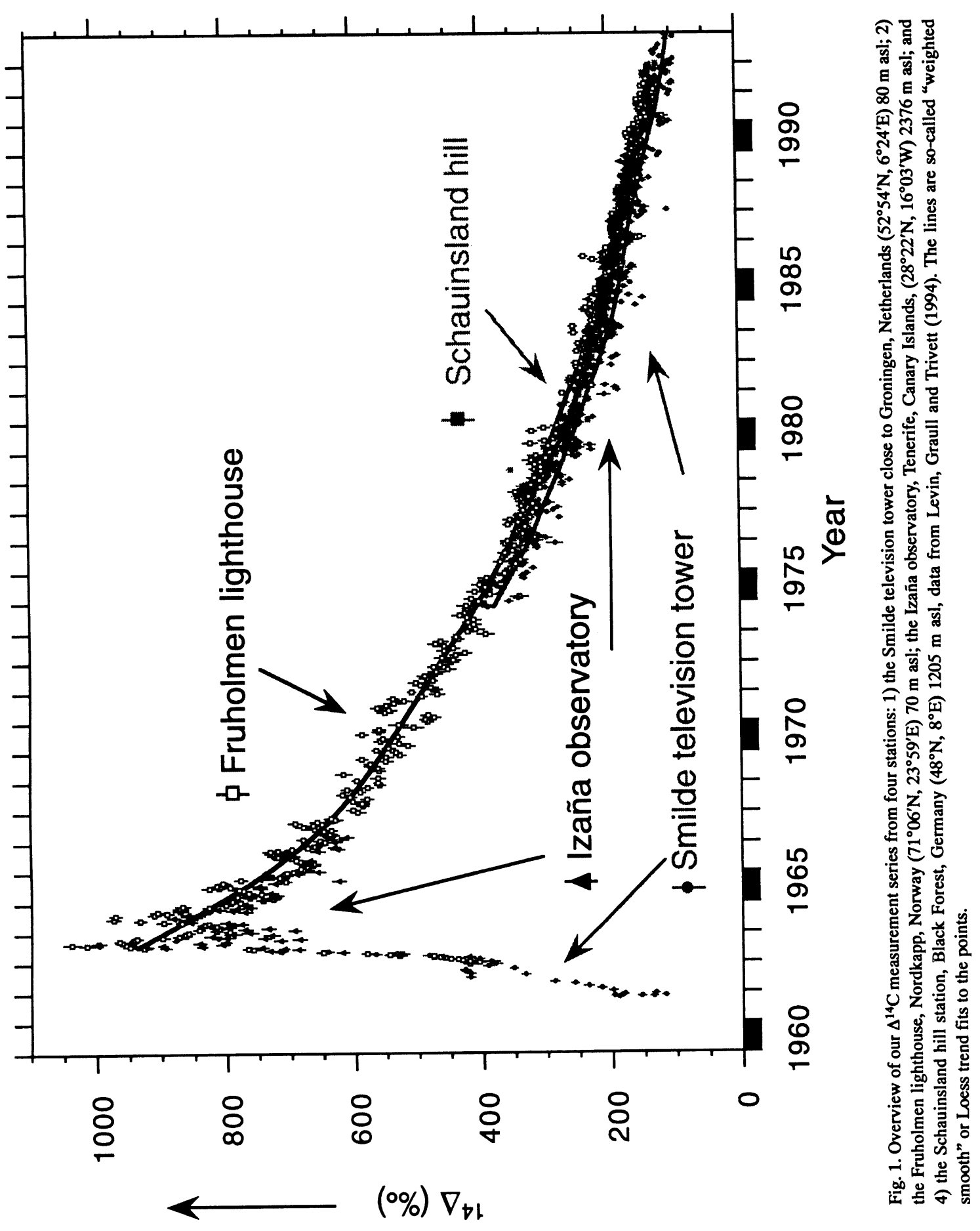


1968) is the main cause for the relatively high decay during that period (characterized by a half-life of $c a .5 \mathrm{yr}$ from 1963-1968 vs. ca. $8 \mathrm{yr}$ thereafter). Then, atmospheric nuclear bomb tests by France (mainly 1966-1968) and China (mainly 1968-1972) led to smaller disturbances, as well as ${ }^{14} \mathrm{C}$ produced by nuclear power plants. At present, a significant part of the annual decrease (ca. 4\%o $\mathrm{yr}^{-1}$ ) is due to the Suess effect (Tans 1978; Levin et al. 1989).

Considering all these effects, we believe the best way to understand the shape of the observed trend is modeling the abovementioned effects, combined with fit results. Examples of such efforts can be found in (Nydal 1968) for the period 1962-1967, or a more recent global approach (Hesshaimer, Heimann and Levin 1994).

\section{Seasonality}

We fitted the detrended (measurements minus the trend fit) Smilde signal with a single harmonic curve and treated the Schauinsland data in the same manner. In the case of the Fruholmen series, two curve fits were applied: one was similar to Smilde, for the period starting May 1977; the other was an exponentially damped harmonic function, fitted to all the data beginning July 1963 . The seasonal fits are shown in Figure 2, whereas the fit results are shown in Table 1.

TABLE 1A. Characteristics of the fitted seasonal functions (single harmonic $A \cos (2 \pi t / T+\varphi)+B$ ). For the Fruholmen curve, only the data since May 1977 were used. The Schauinsland curve (Levin, Graul and Trivett 1994) was treated similarly to the others, and is given for comparison.

\begin{tabular}{lcccc} 
Station & Peak-to-trough & Maximum & $\begin{array}{c}\text { Residual standard } \\
\text { deviation }(\%)\end{array}$ & $\begin{array}{c}\text { Average measurement } \\
\text { uncertainty }(\%)\end{array}$ \\
\hline Fruholmen & $12.4 \pm 1.6$ & Aug. $29 \pm 7 \mathrm{~d}$ & 10.0 & 6.0 \\
Izaña & $5.4 \pm 2.0$ & July $14 \pm 20 \mathrm{~d}$ & 7.6 & 5.0 \\
Smilde & $31.0 \pm 3.0$ & July $11 \pm 5 \mathrm{~d}$ & 11.6 & 6.0 \\
Schauinsland & $12.0 \pm 1.2$ & Aug. $28 \pm 5 \mathrm{~d}$ & 8.3 & 4.3 \\
\hline
\end{tabular}

TABLE 1B. The full Fruholmen curve has been fitted here, to an exponentially damped harmonic curve $(A \cos (2 \pi t / T+\varphi)+B) \times e^{-C t / T}+D$. The damping characteristic time gives a good indication of the stratosphere-troposphere interaction time. In $A$ and $B$, the remaining undamped part of the full fit curve is the same within the error bars as the single harmonic fit to the "damped" part of the Fruholmen data, both in phase and amplitude.

\begin{tabular}{lccccc} 
Station & $\begin{array}{c}\text { Peak to trough (\%o) } \\
\text { (fully damped) }\end{array}$ & Maximum & Damping $\mathrm{t}_{1 / 2}$ & $\begin{array}{c}\text { Residual standard } \\
\text { deviation }(\% 0)\end{array}$ & $\begin{array}{c}\text { Average measurement } \\
\text { uncertainty (\%o) }\end{array}$ \\
\hline Fruholmen & $12.4 \pm 2.0$ & Aug $23 \pm 3 \mathrm{~d}$ & $2.1 \pm 0.3 \mathrm{yr}$ & 16.2 & 8 \\
\hline
\end{tabular}

The Fruholmen seasonality signal is important because it contains a record of very high amplitudes from the period of clear disequilibrium between stratosphere and troposphere, as well as the later record of stabilized amplitudes. Comparing Tables $1 \mathrm{~A}$ and $1 \mathrm{~B}$, one observes that the remaining undamped part of the full-fit curve is the same within the error bars as the single harmonic fit to the "damped" part of the Fruholmen data. This suggests that a considerable part of the remaining seasonality in the signal is still due to stratospheric input. On the other hand, the Fruholmen seasonality resembles the Schauinsland signal in both phase and amplitude. This station, at an elevation of $c a$. $1200 \mathrm{~m}$ in the Black Forest region of southwest Germany, has been affected by anthropogenically induced emission (Levin et al. 1989), which causes the major part of its seasonality. 

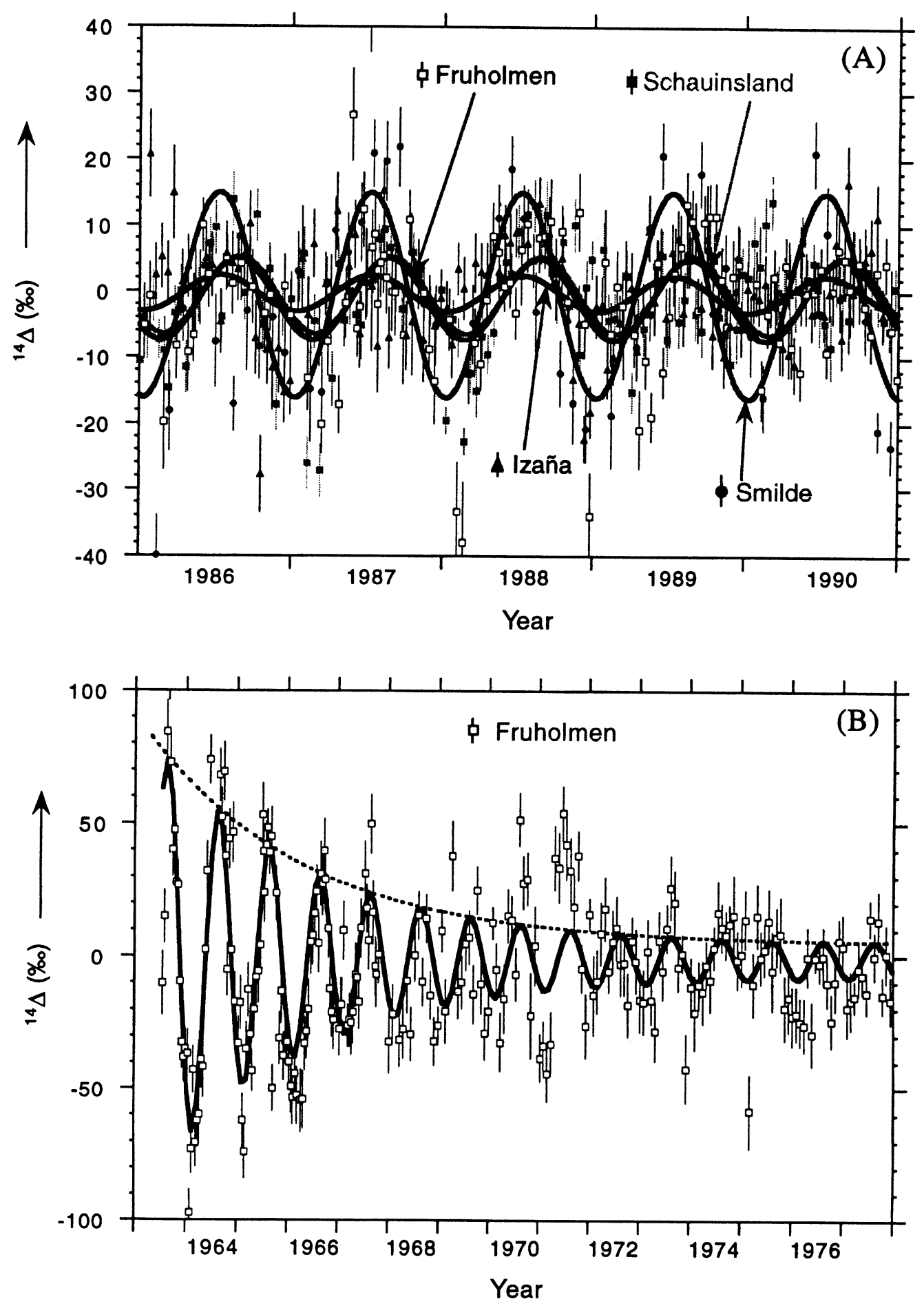

Fig 2. A. The detrended (measurements minus the trend fit) measurement series, fitted with a single harmonic curve, since May 1977. Shown is the part for the years 1986-1991. B. The detrended Fruholmen series, fitted with an exponentially damped harmonic function, fitted to all the data since July 1963. Shown is the part for the years 1963-1977. 
The continental Smilde record shows relatively high seasonality, obviously caused by the summerwinter difference in fossil-fuel emissions (combined with the seasonal variation in average mixing layer thickness). The Smilde oscillation is somewhat out of phase with that of Fruholmen; its minimum at mid-January coincides with the coldest part of winter in northwestern Europe.

The comparison in Table $1 \mathrm{~A}$ of the residual standard deviation to the average measurement uncertainty in the respective series shows that all series suffer from random fluctuations, most probably correlated with meteorological circumstances. Furthermore, the seasonality of the signal shows irregularities on a year-to-year basis.

\section{Absolute Values}

All the stations discussed here were operative during the period 1980-1990, which makes this period the most useful for comparison of absolute values. Figure 3 shows the weighted smooth fits of all four stations for this period. Here the time response of the fits allows the fit curves to follow intra-annual variations. To show the difference clearly, we subtracted an exponentially decaying curve with a half-life of $8 \mathrm{yr}$ from all curves. This procedure should not be taken to represent a "best fit" of the measurements.

As expected, the Smilde values are generally lower than the Fruholmen values. In summer, however, the difference is much smaller than in winter. For the three background stations, the differences between Fruholmen on the one hand, and Izaña and Schauinsland, on the other, seem to decrease

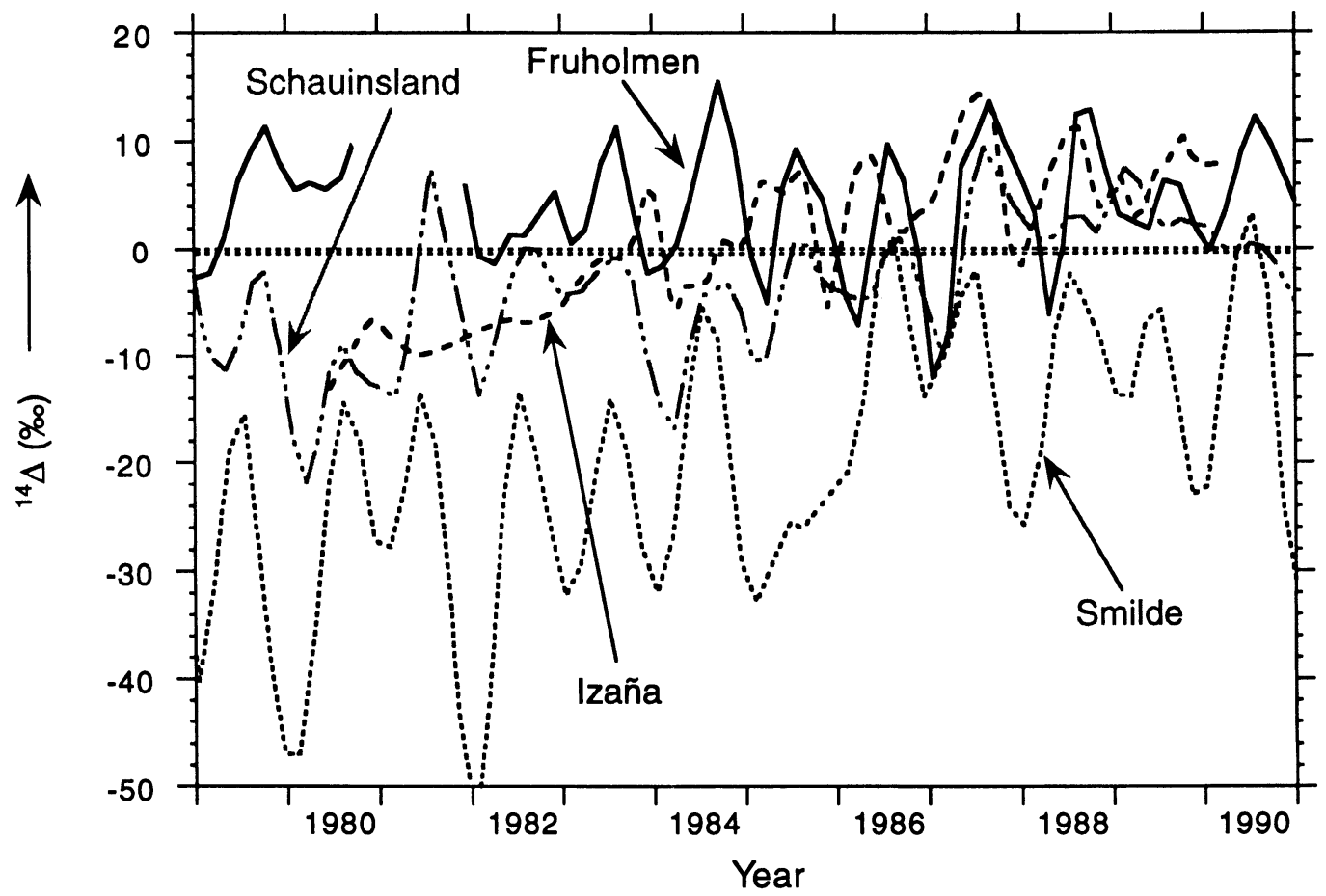

Fig. 3.Weighted smooth fits of all four stations between 1979 and 1990 . The time response of the fits allowed the fit curves to follow intra-annual variations. To make the differences in absolute values more clearly visible we subtracted an exponentially decaying curve with a half-life of 8 yr. The zero on the $y$-axis is arbitrary. 
between 1980 and 1990. It should be noted that these are relatively small effects, and that all measurement series show a considerable residual standard deviation (compare Table 1).

\section{TRITIUM IN PRECIPITATION}

Tritium provides additional information about the stratosphere-troposphere interaction. The Groningen laboratory has measured ${ }^{3} \mathrm{H}$ in precipitation continuously since 1972.

Precipitation water is collected monthly, reduced over hot magnesium, and its hydrogen transmuted into ethene. This acts as a counting gas in a proportional counter, belonging to the same low-activity setup as the $\mathrm{CO}_{2}$ counters for ${ }^{14} \mathrm{C}$. The data are available through the IAEA (1994). The activity is expressed in tritium units (TU). One TU is equivalent to a ${ }^{3} \mathrm{H}$ activity of $0.118 \mathrm{~Bq}$ liter ${ }^{-1} \mathrm{H}_{2} \mathrm{O}$. Activity and monthly amount of precipitation must then be combined to produce the monthly ${ }^{3} \mathrm{H}$ activity from precipitation per square meter. Figure 4 gives an overview of these results. We obtained average TU by dividing the activity numbers by the average monthly precipitation $(62 \mathrm{~mm} / \mathrm{month})$, thus circumventing the convolution of the ${ }^{3} \mathrm{H}$ deposit with the seasonality of the amount of precipitation.

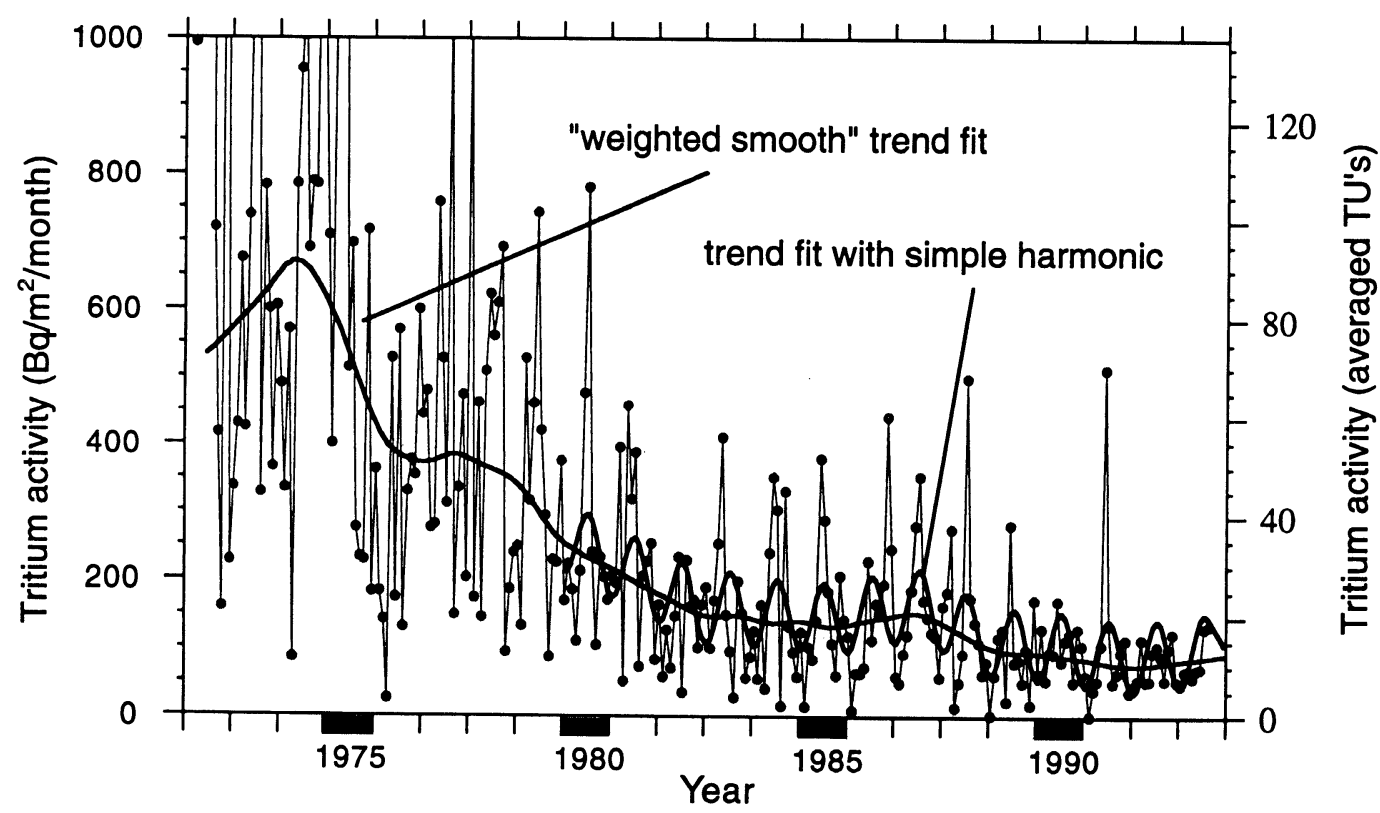

Fig. 4.The ${ }^{3} \mathrm{H}$ activity in precipitation in Groningen $\left(52^{\circ} 15^{\prime} \mathrm{N}, 6^{\circ} 33^{\prime} \mathrm{E}\right) 0 \mathrm{~m}$ asl. On the left-hand $\mathrm{y}$-axis, the activity is expressed in $\mathrm{Bq} \mathrm{m}^{-2}$ per month. These numbers are obtained by multiplying the measured activity of the precipitation (in TU or $0.118 \mathrm{~Bq} \mathrm{liter}^{-1}$ water) with the monthly amount of precipitation. The right-hand $\mathrm{y}$-axis is expressed in average TU, obtained by dividing the left-hand scale activity numbers by the average monthly precipitation $(62 \mathrm{~mm} / \mathrm{month})$. Two fits to the data are shown: a weighted smooth trend fit and a "full fit" (from 1981 onwards), consisting of the above trend with a single harmonic.

We show two fits to the curves: 1) a weighted smooth trend fit, showing an irregularly decaying trend. This irregularity is caused by the bomb tests in the 1970s; 2) a "full fit" (since 1981), consisting of the above trend with a single harmonic. The peak-to-peak value for the harmonic is $104 \pm 22$ $\mathrm{Bq} \mathrm{m}^{-2}(14 \pm 3 \mathrm{TU})$; the maximum occurs mid-July. A fit to the "direct" TU values yields the same amplitude within the uncertainty bars, but the maximum occurs mid-June. 
In recent years the values generally move between $\sim 40 \mathrm{~Bq} \mathrm{~m}^{-2}(5 \mathrm{TU})$ in winter and $140 \mathrm{~Bq} \mathrm{~m}^{-2}(20$ $\mathrm{TU}$ ) in summer. The average value is still decreasing, although in recent years at a slower rate. The amplitude of the harmonic seems to be constant over the last $10 \mathrm{yr}$.

\section{Discussion}

Levin et al. (1989) have studied the influence of fossil fuel in the Schauinsland measurements by comparing the Schauinsland values to those of background station Jungfraujoch. Assuming that the Jungfraujoch series is fairly clean, the authors found $15 \%$ in winter, and $5 \%$ in summer. The average difference between the Smilde and Schauinsland full fits is 27\%o in winter and 4\%o in summer. Combining these numbers with the Levin et al. (1989) data, and taking into account the phase difference between the two stations, we conclude that fossil-fuel contributions for the Smilde series are ca. $40 \%$ or $14 \mathrm{ppm}$ in winter, and $9 \%$ or $3 \mathrm{ppm}$ in summer.

These computations cannot be applied to the Fruholmen and Izaña stations, because they are too far away. The differences in absolute values between the curves change considerably between 1979 and 1990, as indicated above. Using only the first $5 \mathrm{yr}$ of Figure 3, one can conclude that Fruholmen is almost undisturbed, with higher values in winter than Schauinsland shows in summer. On the other hand, if one uses the amplitude of the seasonal cycle as an indicator of fossil-fuel influence, it would imply that Fruholmen also suffers from fossil-fuel influences in winter, of about the same size as Schauinsland. Absolute values in the Izaña curve from 1979-1984 indicate that the station is quite affected by fossil-fuel emissions throughout the year, whereas the small amplitude of the seasonal cycle indicates an undisturbed background station.

Clearly, the situation is more complicated. Apart from possible experimental problems (e.g., sample site changes, pretreatment uncertainties, calibration problems), which only comparison with data of other northern hemisphere stations can elucidate, other factors such as enhanced (seasonal) stratospheric input at higher latitudes, or influences by the oceans must also play a role. Furthermore, it is quite conceivable that the part of the terrestrial biosphere (typically soils) that interacts slowly with the troposphere presently acts as a net ${ }^{14} \mathrm{C}$ source with a summer-winter periodicity (Hesshaimer, personal communication 1995). The main point of discussion is the amplitude of the natural seasonal effect, caused by the annual "injection" of ${ }^{14} \mathrm{C}$ from the stratosphere into the troposphere (Tans 1978). The periodicity of this effect is clearly illustrated in the Fruholmen series between 1963 and 1970, where a clear stratosphere-troposphere disequilibrium existed. Presently, at least in Europe, the periodicity of fossil-fuel emission seems to be the dominant cause of seasonality, even in such remote places as Fruholmen.

${ }^{3} \mathrm{H}$ is much more influenced by nuclear bomb testing than is ${ }^{14} \mathrm{C}$. In summer 1963 , the average precipitation activity was $c a .3800 \mathrm{TU}\left(230 \mathrm{kBq} \mathrm{m}^{-2}\right)$, or $c a .700$ times the pre-bomb activity (IAEA 1979). The fast decay of this activity is caused both by the short half-life of ${ }^{3} \mathrm{H}\left(\mathrm{t}_{1 / 2}=12.3 \mathrm{yr}\right)$, and the huge existing reservoir with short interaction times. The ocean mixing layer (taken here as 130 $\mathrm{m}$ ) contains $\mathrm{ca} .5 \times 10^{7} \mathrm{GT}$ water compared to $13,000 \mathrm{GT}$ water vapor in the atmosphere, resulting in a rapid 1:4000 dilution, whereas in the case of ${ }^{14} \mathrm{CO}_{2}$, the ratio atmosphere:(ocean mixing layer + land biosphere) is only $c a$. 1:2 (Schlesinger 1991, and references therein). A strong seasonal signal is clearly visible, although the scatter in the signal is considerable. This scatter is caused by the irregular character of rainfall.

Because of the high mixing rate, together with the short decay time, it is probable that at least the seasonal cycle observed in ${ }^{3} \mathrm{H}$ is close to its natural value. On the other hand, soil and groundwater reservoirs can be found with relatively high ${ }^{3} \mathrm{H}$ content, and, especially in summer, it could well be 
that soil water evaporation acts as a net ${ }^{3} \mathrm{H}$ source, thereby enhancing the natural seasonality. It is most likely that considerable natural seasonality exists. Stratosphere-troposphere interaction has a pulsed character, whereas the troposphere mixing is very fast for water (the annual amount of precipitation is ca. 40 times as high as the water-vapor content of the troposphere (Schlesinger 1991)).

In the case of steady state, stratospheric production and stratosphere-troposphere exchange of cosmogenic isotopes must balance the loss of these isotopes in the troposphere caused by decay. Using as input the amounts of water for the oceanic mixing layer and total precipitation mentioned above, it is simple to compute that the measured seasonality is able to maintain a (mixing layer + troposphere) ${ }^{3} \mathrm{H}$ background level of $c a$. $1.5 \mathrm{TU}$. Unfortunately, we know of no reliable data for seasonality in precipitation and upper ocean natural ${ }^{3} \mathrm{H}$ values preceding the bomb tests.

For ${ }^{14} \mathrm{C}$, a similar simple computation (using the fact that ${ }^{14} \mathrm{C}$ decays by $0.125 \%$ oer year, and that the troposphere contains $1 / 55$ of the total global reservoirs (Schlesinger 1991)) leads to the conclusion that a replenishment of $7 \%$ is needed for steady-state conditions. If we assume that the troposphere gets this total "refill" in a pulse-like manner (which is illustrated in the early Fruholmen measurements), the natural summer-winter difference cannot be more than this 7\%o (and is most likely considerably lower). This shows that, from the measurement series presented here, the seasonality of only the Izaña record can be totally natural.

A new air monitoring station close to Smilde (Kollumerwaard), where the Groningen group recently started ${ }^{14} \mathrm{CO}_{2}$ (as well as stable isotope) measurements with high temporal resolution (so-called "event-trapping") could shed more light on the amount of fossil-fuel $\mathrm{CO}_{2}$ admixtures and their seasonality (Zondervan and Meijer 1995).

\section{REFERENCES}

Broecker, W. S., Peng, T. H., Östlund, G. and Stuiver, M. 1985 The distribution of bomb radiocarbon in the ocean. Journal of Geophysical Research 90(C4): $6953-6970$.

CDIAC (Carbon Dioxide Information Analysis Center) database, Oak Ridge, Tennessee, Oak Ridge National Laboratory. Internet URL: http://cdiac.esd.ornl.gov/ cdiac/.

Cleveland, W. S., and McRae, J. E. 1989 The use of loess and STL in the analysis of atmospheric $\mathrm{CO}_{2}$ and related data. In Elliot, W. P., ed., The Statistical Treatment of $\mathrm{CO}_{2}$ Data Records. Silver Spring, Maryland, NOAA Tech memo ERL ARL-173.

Gislefoss, J. S. 1994. (ms.) Carbon Profiles in the Nordic Seas. Ph.D. dissertation, Radiological Dating Laboratory, UNIT/NTH, Trondheim, Norway.

IAEA 1979 Behaviour of Tritium in the Environment, Proceedings of an International Symposium on the Behaviour of Tritium, San Francisco 1978. Vienna, IAEA proceedings series 498.

1994 Environmental Isotope Data No. 10. Vienna, IAEA Technical Reports series no. 371.

Hesshaimer, V., Heimann, M. and Levin, I. 1994 Radiocarbon evidence for a smaller oceanic carbon dioxide sink than previously believed. Nature 370: 201-203.

Levin, I., Graul, R. and Trivett, N. B. A. 1995 Long term observations of atmospheric $\mathrm{CO}_{2}$ and carbon isotopes

at continental sites in Germany. Tellus 47B(1/2): 2324.

Levin, I., Münnich, K. O., and Weiss, W. 1980 The effect of anthropogenic $\mathrm{CO}_{2}$ and ${ }^{14} \mathrm{C}$ sources on the distribution of ${ }^{14} \mathrm{C}$ in the atmosphere. In Stuiver, M. and $\mathrm{Kra}$, R. S., eds, Proceedings of the 10th International ${ }^{14} \mathrm{C}$ conference. Radiocarbon 22(2): 379-391.

Levin, I., Schuchard, J., Kromer, B., and Münnich, K. 0. 1989 The continental European Suess effect. In Long, A. and Kra, R. S., eds, Proceedings of the 13th International ${ }^{14} \mathrm{C}$ conference. Radiocarbon 31(3): 431440.

Manning, M. R., Lowe, D. C., Melhuish, W. H., Sparks, R. J., Wallace, G., Brenninkmeijer, C. A. M. and McGill, R. C. 1990 The use of radiocarbon measurements in atmospheric studies. Radiocarbon 32(1): 3758.

Münnich, K. O. and Vogel, J. C. 1958 Durch Atomexplosionen erzeugter Radiokohlenstoff in der Atmosphäre. Naturwissenschaften 45: 327-329.

Nydal, R. 1966 Variation in ${ }^{14} \mathrm{C}$ concentration in the atmosphere during the last several years. Tellus 18(2): 271-279.

1968 Further investigation of the transfer of radiocarbon in nature. Journal of Geophysical Research 73: 3617-3634.

1991. Exchange of $\mathrm{CO}_{2}$ between the atmosphere 
and the ocean. Norsk Geologisk Tidsskrift 71: 199201.

Nydal, R., Gulliksen, S., Lövseth, K. and Skogseth, F. H. 1984 Bomb ${ }^{14} \mathrm{C}$ in the ocean surface $1966-1981$. Radiocarbon 26(1): 7-45.

Nydal, R. and Lövseth, K. 1983 Tracing Bomb ${ }^{14} \mathrm{C}$ in the atmosphere 1962-1980. Journal of Geophysical Research 88: 3621-3642.

Schlesinger, W.H. 1991 Biogeochemistry: An Analysis of Global Change. San Diego, California, Academic Press: 443 p.

Stuiver, M. and Polach, H. A. 1977 Discussion: Reporting of ${ }^{14} \mathrm{C}$ data. Radiocarbon 19(3): 355-363.

\section{APPENDIX 1. SMILDE ${ }^{14} \mathrm{C}$ DATE LIST}

\begin{tabular}{|c|c|c|c|}
\hline Month & $\begin{array}{l}\Delta^{14} \mathrm{C} \\
(\% 0)\end{array}$ & $\begin{array}{c}\Delta^{14} C \text { unc. } \\
(\% 0)\end{array}$ & $\begin{array}{c}\delta^{13} \mathrm{C} \\
\left(\%_{0} \text { VPDB }\right)\end{array}$ \\
\hline Nov. 1974 & 389 & 9 & -8.55 \\
\hline Dec. 1974 & 393 & 10 & -8.48 \\
\hline Jan. 1975 & 356 & 6 & -8.51 \\
\hline Feb. 1975 & 342 & 7 & -9 \\
\hline Mar. 1975 & 391 & 9 & -10.15 \\
\hline Apr. 1975 & 370 & 6 & -8.4 \\
\hline May. 1975 & 389 & 6 & -8.46 \\
\hline Jun. 1975 & 368 & 6 & -7.47 \\
\hline Jul. 1975 & 376 & 6 & -8.46 \\
\hline Aug. 1975 & 382 & 5 & -8.66 \\
\hline Sep. 1975 & 365 & 6 & -8.53 \\
\hline Oct. 1975 & 333 & 6 & -9.18 \\
\hline Nov. 1975 & 335 & 6 & -8.87 \\
\hline Dec. 1975 & 328 & 6 & -8.73 \\
\hline Jan. 1976 & 350 & 6 & -8.51 \\
\hline Feb. 1976 & 318 & 6 & -9.32 \\
\hline Mar. 1976 & 336 & 6 & -9.09 \\
\hline Apr. 1976 & 332 & 6 & -9.08 \\
\hline May. 1976 & 353 & 6 & -8.38 \\
\hline Jun. 1976 & 345 & 6 & -7.89 \\
\hline Jul. 1976 & 342 & 6 & -8.27 \\
\hline Aug. 1976 & 342 & 6 & -7.55 \\
\hline Sep. 1976 & 330 & 6 & -7.93 \\
\hline Oct. 1976 & 312 & 6 & -8.22 \\
\hline Nov. 1976 & 312 & 6 & -8.91 \\
\hline Dec. 1976 & 284 & 13 & -9.54 \\
\hline Jan. 1977 & 311 & 10 & -9.15 \\
\hline Feb. 1977 & 298 & 10 & -8.95 \\
\hline Mar. 1977 & 310 & 10 & -9 \\
\hline Apr. 1977 & 320 & 10 & -8.7 \\
\hline May. 1977 & 321 & 6 & -8.88 \\
\hline Jun. 1977 & 335 & 6 & -8.07 \\
\hline Jul. 1977 & 336 & 6 & -7.23 \\
\hline Aug. 1977 & 331 & 6 & -7.67 \\
\hline Sep. 1977 & 325 & 6 & -13.08 \\
\hline Oct. 1977 & 277 & 6 & -9.48 \\
\hline Nov. 1977 & 310 & 6 & -8.39 \\
\hline Dec. 1977 & 296 & 5 & -9.86 \\
\hline Jan. 1978 & 286 & 4 & -9.53 \\
\hline Feb. 1978 & 279 & 7 & -9.67 \\
\hline Mar. 1978 & 298 & 6 & -8.63 \\
\hline
\end{tabular}

Tans, P. P. 1978 (ms.) Carbon 13 and Carbon 14 in Trees and the Atmospheric $\mathrm{CO}_{2}$ increase. Ph.D. Dissertation, University of Groningen.

Vogel, J. C. 1970 Groningen radiocarbon dates IX. Radiocarbon 12(2): 444-471.

Zondervan, A, and Meijer, H. A. J. 1995 The start of an "event trapping" air monitoring station at Kollumerwaard, NL. In Rozanski, K., ed., Isotope Variations of Carbon Dioxide and other Trace Gases in the Atmosphere. Final Report of the Final Research Coordinating Meeting, Vienna, November 7-10, 1994. Vienna, Austria, IAEA.

\begin{tabular}{|c|c|c|c|}
\hline Month & $\begin{array}{l}\Delta^{14} \mathrm{C} \\
(\% 0)\end{array}$ & $\begin{array}{c}\Delta^{14} C \text { unc. } \\
(\% \text { o })\end{array}$ & $\begin{array}{c}\delta^{13} \mathrm{C} \\
(\% \circ \text { VPDB })\end{array}$ \\
\hline Apr. 1978 & 292 & 9 & -9.54 \\
\hline May. 1978 & 309 & 4 & -9.8 \\
\hline Jun. 1978 & 331 & 7 & -8.08 \\
\hline Jul/Aug. 1978 & 334 & 6 & -7.75 \\
\hline Sep. 1978 & 330 & 6 & -8.07 \\
\hline Oct. 1978 & 298 & 6 & -8.32 \\
\hline Nov. 1978 & 272 & 6 & -9.11 \\
\hline Dec. 1978 & 271 & 6 & -8.9 \\
\hline Jan. 1979 & 260 & 6 & -9.55 \\
\hline Feb. 1979 & 274 & 6 & -10.15 \\
\hline Mar. 1979 & 274 & 8 & -8.6 \\
\hline Apr. 1979 & 280 & 6 & -8.92 \\
\hline May. 1979 & 310 & 9 & -8.47 \\
\hline Jun. 1979 & 298 & 6 & -8.87 \\
\hline Jul. 1979 & 285 & 6 & -8.14 \\
\hline Aug. 1979 & 280 & 5 & - 7.99 \\
\hline Oct. 1979 & 250 & 6 & -8.88 \\
\hline Nov. 1979 & 246 & 7 & -9.32 \\
\hline Dec. 1979 & 255 & 5 & -9.25 \\
\hline Jan. 1980 & 226 & 6 & -9.1 \\
\hline Feb. 1980 & 244 & 7 & -9.07 \\
\hline Mar. 1980 & 228 & 9 & -9.13 \\
\hline Apr. 1980 & 244 & 7 & -9.09 \\
\hline May. 1980 & 265 & 12 & -8.98 \\
\hline Jun. 1980 & 262 & 6 & -9.48 \\
\hline Jul. 1980 & 267 & 6 & -9.05 \\
\hline Aug. 1980 & 261 & 5 & -8.17 \\
\hline Sep. 1980 & 267 & 6 & -8.51 \\
\hline Oct. 1980 & 268 & 6 & -7.55 \\
\hline Nov. 1980 & 246 & 5 & -7.5 \\
\hline Dec. 1980 & 244 & 6 & -8.42 \\
\hline Feb. 1981 & 224 & 6 & -7.03 \\
\hline Mar. 1981 & 240 & 6 & -8.08 \\
\hline Apr. 1981 & 257 & 4 & -6.99 \\
\hline May. 1981 & 243 & 4 & -6.64 \\
\hline Jun. 1981 & 251 & 4 & -8.29 \\
\hline Jul. 1981 & 251 & 5 & -8.73 \\
\hline Aug. 1981 & 265 & 6 & -7.38 \\
\hline Sep. 1981 & 229 & 5 & -8.02 \\
\hline Oct. 1981 & 232 & 6 & -8.82 \\
\hline Nov. 1981 & 205 & 10 & -8.52 \\
\hline
\end{tabular}




\begin{tabular}{|c|c|c|c|}
\hline Month & $\begin{array}{l}\Delta^{14} \mathrm{C} \\
(\% 0) \\
\end{array}$ & $\begin{array}{c}\Delta^{14} \mathrm{C} \text { unc. } \\
(\$ 00)\end{array}$ & $\begin{array}{c}\delta^{13} \mathrm{C} \\
(\% \circ \text { VPDB })\end{array}$ \\
\hline Jan. 1982 & 185 & 6 & -10.71 \\
\hline Feb. 1982 & 188 & 6 & -9.02 \\
\hline Mar. 1982 & 204 & 6 & -10.24 \\
\hline Apr. 1982 & 243 & 12 & -7.7 \\
\hline May. 1982 & 235 & 6 & -8.57 \\
\hline Jul. 1982 & 227 & 6 & -7.44 \\
\hline Aug. 1982 & 238 & 6 & -8 \\
\hline Sep. 1982 & 220 & 5 & -8.87 \\
\hline Oct. 1982 & 220 & 5 & -8.84 \\
\hline Nov. 1982 & 194 & 6 & -6.34 \\
\hline Dec. 1982 & 210 & 6 & -8.5 \\
\hline Jan. 1983 & 212 & 5 & -8.69 \\
\hline Feb. 1983 & 193 & 6 & -8.15 \\
\hline Mar. 1983 & 186 & 6 & -8.06 \\
\hline Apr. 1983 & 207 & 6 & -8.88 \\
\hline May. 1983 & 215 & 5 & -8.27 \\
\hline Jun. 1983 & 208 & 6 & -8.05 \\
\hline Jul. 1983 & 225 & 6 & -8.29 \\
\hline Aug. 1983 & 217 & 6 & -10.72 \\
\hline Sep. 1983 & 208 & 6 & -10.48 \\
\hline Oct. 1983 & 194 & 5 & -9.07 \\
\hline Nov. 1983 & 190 & 6 & -9.58 \\
\hline Dec. 1983 & 191 & 6 & -9.26 \\
\hline Jan. 1984 & 191 & 6 & -8.86 \\
\hline Feb. 1984 & 180 & 6 & -9.11 \\
\hline Mar. 1984 & 183 & 6 & -9.1 \\
\hline Apr. 1984 & 196 & 5 & -8.79 \\
\hline May. 1984 & 200 & 6 & -8.57 \\
\hline Jun. 1984 & 210 & 6 & -8.21 \\
\hline Jul. 1984 & 214 & 6 & -8.15 \\
\hline Sep. 1984 & 202 & 5 & -7.97 \\
\hline Oct. 1984 & 204 & 5 & -8.31 \\
\hline Nov. 1984 & 156 & 5 & -9.19 \\
\hline Dec. 1984 & 177 & 5 & -9.03 \\
\hline Feb. 1985 & 145 & 6 & -9.11 \\
\hline Mar. 1985 & 166 & 6 & -9.03 \\
\hline Apr. 1985 & 181 & 5 & -8.75 \\
\hline May. 1985 & 182 & 7 & -8.14 \\
\hline Jun/Jul. 1985 & 174 & 7 & -10.15 \\
\hline Aug. 1985 & 163 & 4 & -8.51 \\
\hline Sep. 1985 & 177 & 9 & -10.36 \\
\hline Oct. 1985 & 171 & 5 & -10.35 \\
\hline Nov. 1985 & 174 & 6 & -9.36 \\
\hline Dec. 1985 & 168 & 5 & -10.49 \\
\hline Jan. 1986 & 180 & 6 & -8.81 \\
\hline Feb. 1986 & 161 & 8 & -9.47 \\
\hline Mar. 1986 & 160 & 6 & -9.81 \\
\hline Apr. 1986 & 184 & 5 & -8.88 \\
\hline May. 1986 & 180 & 6 & -9.2 \\
\hline Jun. 1986 & 184 & 6 & -9.75 \\
\hline Jul. 1986 & 193 & 5 & -10.13 \\
\hline Aug. 1986 & 191 & 6 & -9.62 \\
\hline Sep. 1986 & 193 & 6 & -8.55 \\
\hline Oct. 1986 & 176 & 6 & -9.92 \\
\hline Nov. 1986 & 168 & 6 & -9.51 \\
\hline Dec. 1986 & 164 & 6 & -9.2 \\
\hline Mar. 1987 & 163 & 6 & -9.59 \\
\hline May. 1987 & 178 & 5 & -10.14 \\
\hline Jun. 1987 & 184 & 5 & -9.36 \\
\hline Jul. 1987 & 176 & 5 & -8.77 \\
\hline
\end{tabular}

\begin{tabular}{|c|c|c|c|}
\hline Month & $\begin{array}{l}\Delta^{14} \mathrm{C} \\
(\% 0)\end{array}$ & $\begin{array}{c}\Delta^{14} \mathrm{C} \text { unc. } \\
(\% 0)\end{array}$ & $\begin{array}{c}\delta^{13} \mathrm{C} \\
(\% 0 \text { VPDB })\end{array}$ \\
\hline Aug. 1987 & 161 & 6 & -8.38 \\
\hline Sep. 1987 & 172 & 6 & -9.86 \\
\hline Oct. 1987 & 151 & 5 & -10.17 \\
\hline Nov. 1987 & 145 & 6 & -11.55 \\
\hline Dec. 1987 & 141 & 5 & -10.63 \\
\hline Jan. 1988 & 106 & 5 & -9.66 \\
\hline Feb. 1988 & 141 & 8 & -9.41 \\
\hline Mar. 1988 & 151 & 6 & -10.42 \\
\hline Apr. 1988 & 149 & 5 & -9.71 \\
\hline May. 1988 & 166 & 5 & -9.86 \\
\hline Jun. 1988 & 176 & 5 & -9.09 \\
\hline Jul. 1988 & 157 & 6 & -10.15 \\
\hline Aug. 1988 & 159 & 5 & -8.72 \\
\hline Sep. 1988 & 170 & 5 & -9.64 \\
\hline Oct. 1988 & 149 & 6 & -10.43 \\
\hline Nov. 1988 & 155 & 5 & -11.48 \\
\hline Dec. 1988 & 155 & 5 & -10.73 \\
\hline Jan. 1989 & 143 & 6 & -10.82 \\
\hline Feb. 1989 & 133 & 5 & -11 \\
\hline Mar. 1989 & 146 & 5 & -10.49 \\
\hline Apr. 1989 & 150 & 5 & -9.82 \\
\hline May. 1989 & 146 & 5 & -10.46 \\
\hline Jun. 1989 & 166 & 5 & -10.16 \\
\hline Jul. 1989 & 154 & 7 & -10.46 \\
\hline Aug. 1989 & 143 & 5 & -10.83 \\
\hline Sep. 1989 & 146 & 6 & -11.14 \\
\hline Oct. 1989 & 138 & 5 & -10.71 \\
\hline Nov. 1989 & 120 & 3 & -11.32 \\
\hline Dec. 1989 & 116 & 4 & -11.19 \\
\hline Jan. 1990 & 126 & 5 & -11.58 \\
\hline Feb. 1990 & 133 & 5 & -11.24 \\
\hline Mar. 1990 & 147 & 5 & -11.35 \\
\hline Apr. 1990 & 140 & 5 & -10.34 \\
\hline May. 1990 & 149 & 5 & -10.54 \\
\hline Jun. 1990 & 151 & 5 & -11.37 \\
\hline Jul. 1990 & 155 & 5 & -10.63 \\
\hline Aug. 1990 & 158 & 5 & -10.25 \\
\hline Sep. 1990 & 143 & 5 & -10.62 \\
\hline Oct. 1990 & 133 & 5 & -11.11 \\
\hline Nov. 1990 & 115 & 5 & -11.04 \\
\hline Dec. 1990 (1) & 109 & 6 & -12.1 \\
\hline Dec. 1990 (2) & 113 & 6 & -10.16 \\
\hline Jan. 1991 & 101 & 5 & -11.49 \\
\hline Feb. 1991 & 115 & 6 & -12.4 \\
\hline Mar. 1991 & 118 & 6 & -11.08 \\
\hline Apr. 1991 & 126 & 5 & -10.66 \\
\hline May. 1991 & 127 & 5 & -11.42 \\
\hline Jun. 1991 & 125 & 5 & -10.28 \\
\hline Jul. 1991 & 132 & 6 & -10.65 \\
\hline Aug. 1991 & 132 & 6 & -9.8 \\
\hline Sep. 1991 & 137 & 5 & -10.5 \\
\hline Oct. 1991 & 120 & 4 & -11 \\
\hline Nov/Dec. 1991 & 103 & 4 & -11.33 \\
\hline Jan. 1992 & 100 & 4 & -10.91 \\
\hline Feb. 1992 & 107 & 6 & -11.14 \\
\hline Mar. 1992 & 113 & 6 & -11.11 \\
\hline Apr. 1992 & 98 & 6 & -10.8 \\
\hline May. 1992 & 96 & 5 & -10.85 \\
\hline Jun. 1992 & 119 & 4 & -10.71 \\
\hline Jul. 1992 & 122 & 6 & -10.25 \\
\hline
\end{tabular}




\begin{tabular}{lrcl}
\hline & $\begin{array}{c}\Delta^{14} \mathrm{C} \\
(\% 0)\end{array}$ & $\begin{array}{c}\Delta^{14} \mathrm{C} \text { unc. } \\
(\% \circ)\end{array}$ & $\begin{array}{c}\delta^{13} \mathrm{C} \\
(\% \circ \text { VPDB })\end{array}$ \\
\hline Month & 104 & 6 & -9.81 \\
Sug. 1992 & 103 & 6 & -10.4 \\
Oct. 1992 & 113 & 6 & -10.31 \\
Nov. 1992 & 107 & 10 & -10.41 \\
Dec. 1992 & 98 & 6 & -11.41 \\
Jan. 1993 & 101 & 4 & -10.51 \\
Feb. 1993 & 95 & 4 & -9.34 \\
Mar. 1993 & 114 & 4 & -8.77 \\
Apr. 1993 & 123 & 4 & -8.58 \\
May. 1993 & 125 & 4 & -8.56 \\
Jun. 1993 & 120 & 4 & -8.61 \\
Jul/Aug. 1993 & 116 & 4 & -8.36 \\
Oct. 1993 & 105 & 4 & -8.71
\end{tabular}

\begin{tabular}{lrcl}
\hline Month & $\begin{array}{r}\Delta^{14} \mathrm{C} \\
(\% 0)\end{array}$ & $\begin{array}{c}\Delta^{14} \mathrm{C} \text { unc. } \\
(\% 0)\end{array}$ & $\begin{array}{c}\delta^{13} \mathrm{C} \\
(\% \circ \text { VPDB })\end{array}$ \\
\hline Nov. 1993 & 95 & 4 & -9.28 \\
Dec. 1993 & 108 & 4 & -8.69 \\
Jan. 1994 & 78 & 4 & -8.91 \\
Feb. 1994 & 74 & 4 & -9.57 \\
Mar. 1994 & 108 & 4 & -8.99 \\
Apr. 1994 & 103 & 4 & -9.35 \\
May 1994 & 105 & 4 & -8.78 \\
June 1994 & 112 & 4 & -8.57 \\
July 1994 & 106 & 4 & -8.42 \\
Aug. 1994 & 111 & 4 & -8.44 \\
Sep. 1994 & 105 & 4 & -8.27 \\
Nov. 1994 & 101 & 4 & -8.87 \\
Dec. 1994 & 100 & 4 & -8.92
\end{tabular}

